\title{
CORRIGENDUM
}

\section{China and Islam: The Prophet, the Party, and Law By Matthew S. Erie, Cambridge and New York: Cambridge University Press, 2016. xviii + 447 pp. ISBN: 978-1-107-05337-3 \$140.00 (hardback) - CORRIGENDUM}

\author{
Mark Fathi Massoud
}

DOI: IO.IOI7/SI744552317000283 Published online: I I July 2017

In the above mentioned article (Massoud, 20I7) the incorrect publisher was given; it was previously

Oxford University Press. This has now been corrected.

The author apologises for this error.

\section{REFERENCE}

Massoud, Mark Fathi (2017). China and Islam: The Prophet, the Party, and Law By Matthew S. Erie,

Cambridge and New York: Cambridge University Press, 20I6. xviii 447 pp. ISBN: 978-I-I0705337-3 \$140.00 (hardback). International Journal of Law in Context, I-4. doi:Io.IoI7/ SI 744552317000283 